\section{Jubileusz pięćdziesięciolecia pracy naukowej Profesora Marcelego Kosmana}

26 października 2011 r. w budynku Wydziału Nauk Politycznych i Dziennikarstwa Uniwersytetu im. Adama Mickiewicza w Poznaniu odbyła się uroczystość mająca na celu uczczenie pięćdziesięciolecia pracy naukowej prof. zw. dra hab. Marcelego Kosmana. Jubileusz został zorganizowany pod honorowym patronatem Jego Magnificencji Rektora UAM prof. dr hab. Bronisława Marciniaka oraz prezydenta miasta Poznania Ryszarda Grobelnego. Obok szacownego Jubilata, jego żony - prof. zw. dr hab. Bogumiły Kosmanowej oraz najbliższej rodziny $\mathrm{w}$ spotkaniu wzięli udział liczni przedstawiciele poznańskiego środowiska naukowego i kulturalnego oraz goście $\mathrm{z}$ innych ośrodków naukowych z kraju (m.in. z Opola, Bydgoszczy, Torunia, Lublina, Krakowa, Warszawy, Gdańska, Kalisza, Inowrocławia) i z zagranicy, w tym m.in. ks. prof. Marek Inglot - dziekan Wydziału Historii Kościoła Papieskiego Uniwersytetu Gregorianum w Rzymie, prof. dr Henryka Ilgiewicz z Wilna i dr Roman Baron z Pragi. Nie mogło również zabraknąć uczniów prof. Kosmana, zarówno tych towarzyszących mu w początkach drogi naukowej, jak również obecnych, którzy z wdzięcznością gratulowali swojemu Mistrzowi.

W jubileuszu prof. Marcelego Kosmana wzięli także udział m.in.: prof. Tomasz Jasiński - dyrektor Biblioteki Kórnickiej, prof. Henryk Olszewski - przewodniczący Rady Naukowej Biblioteki Kórnickiej, prof. Tadeusz Bujnicki - ceniony sienkiewiczolog, ks. prof. Ludwik Grzebień, ks. prof. Janusz Zbudniewek, prof. Stanisław Obirek, prof. Włodzimierz Kaczorowski, prof. Bronisław Pasierb, prof. Krzysztof Mikulski - prezes Polskiego Towarzystwa Historycznego, prof. Janusz Małłek, prof. Tomasz Kempa oraz wydawca księgi poświęconej rocznicy $\mathrm{dr}$ Adam Marszałek.
Spotkanie rozpoczęło się od powitania zebranych przez gospodarza uroczystości - prof. Tadeusza Wallasa, dziekana Wydziału Nauk Politycznych i Dziennikarstwa UAM. W dalszej kolejności dziekan przedstawił drogę naukową Jubilata, wskazując na główne jej etapy: matura w rodzinnej Izbicy Kujawskiej (1957); studia historyczne (magisterium na seminarium prof. Gerarda Labudy - 1961); studia pedagogiczne (na ówczesnym Wydziale Filozoficzno-Historycznym UAM - 1964 roku), doktorat (pod kierunkiem prof. Henryka Łowmiańskiego - 1966), habilitacja (1971), tytuły profesora nadzwyczajnego (1980) i zwyczajnego (1988). Długoletnia praca naukowa prof. Kosmana wiązała się z dużą aktywnością na polu dydaktycznym, naukowym i organizatorskim. Dziekan Wallas przypomniał, że Jubilat pracował w latach 1961-1681 jako nauczyciel języka łacińskiego i polskiego oraz wychowania obywatelskiego w Liceum Ogólnokształcącym w Izbicy Kujawskiej, gdzie również pełnił funkcję dyrektora. Następnie zatrudniony był na stanowisku adiunkta, później zaś docenta w Zakładzie Historii Pomorza Instytutu Historii PAN w Poznaniu. Prof. Marceli Kosman był także dyrektorem Biblioteki Kórnickiej PAN (1976-1982) oraz pracował w Instytucie Historii ówczesnej Wyższej Szkoły Pedagogicznej w Opolu (m.in. jako kierownik Katedry Historii Europy Wschodniej). Od 1987 roku jest nieprzerwanie związany z UAM w Poznaniu: z Instytutem, a następnie $\mathrm{z}$ Wydziałem NPiD, gdzie dzięki jego inicjatywie powstał Zakład Kultury Politycznej, którego jest kierownikiem. Prof. T. Wallas dodał także, że Jubilat został odznaczony m.in. Złotym Krzyżem Zasługi, Krzyżem Kawalerskim Orderu Odrodzenia Polski, Medalem Komisji Edukacji Narodowej oraz Medalem imienia Franciszka Palacky’ego Czeskiej Akademii Nauk w Pradze. 
Następnie prof. Tadeusz Wallas odczytał pismo gratulacyjne JM Rektora UAM prof. $\mathrm{dr}$ hab. Bronisława Marciniaka skierowane do Jubilata. W dalszej kolejności głos zabrała prof. dr hab. Iwona Hofman, która przedstawiła bogaty dorobek naukowy, popularnonaukowy i pisarski prof. Marcelego Kosmana. Ważnym akcentem spotkania było wręczenie Jubilatowi 2-tomowej księgi pamiątkowej zatytułowanej Przez Kresy i Historię po obrzeża polityki. W księdze tej znalazło się ponad pięćdziesiąt tekstów odzwierciedlających zainteresowania naukowe bohatera uroczystości. Odnotować należy fakt, że Jubilat otrzymał szereg listów gratulacyjnych, o których poinformował zebranych dr Piotr Forecki. Następnie w imieniu 16 wypromowanych dotychczas doktorów wyrazy wdzięczności przekazał najmłodszy z nich stażem dr Bartłomiej Secler.

Kolejnym elementem spotkania były wypowiedzi zebranych na uroczystości gości. Jako pierwszy głos zabrał dr Andrzej Gąszczołowski, który odczytał list byłego prezydenta Rzeczypospolitej Polskiej gen. Wojciecha Jaruzelskiego do Jubilata, w którym znalazły się m.in. następujące słowa: Wysoko cenie wiedze $i$ postawe Pana Profesora uczonego odważnie przeciwstawiajacego sie instrumentalizowaniu historii, idacego pod prad aktualnej polityki historycznej, broniacego prawdy o dylematach $i$ wyborach, zwłaszcza dekady lat osiemdziesiatych. Liczne ksiażki i publikacje pisane przez Pana Profesora sktaniaja do refleksji, do gtębokiego namystu nad biegiem polskich dziejów. $Z$ taka myśla dziękuję $i$ z takim przestaniem odczytuję Los Generała.

Interesujące było wystapienie poety $\mathrm{dr}$ Lecha Konopińskiego, członka poznańskiego oddziału Związku Literatów Polskich, który odczytał Dytyramb na pótwiecze Mistrza Marcelego Kosmana profesora zwyczajnego - doktora habilitowanego. Warto w tym miejscu przytoczyć fragment tego utworu:

W Ojczyźnie naszej jubileusze daja Rodakom moc silnych wzruszeń, lecz nic nie wzrusza nas tak jak jesień, która historii plon ku nam niesie!

Z barwnymi liśćmi mknie wieść radosna, ze czci pótwiecze Marceli Kosman Badacz lat ważych - tlustych i chudych; Druh Łowmiańskiego, Kompan Labudy $i$ dziejopisów wierny Przyjaciel, którego pasje poznawcza znacie $i$ dobrze wiecie jak wazne dla nas jest to pótwiecze Mistrza Kosmana.

W dalszej kolejności głos zabrali dr Marian Król - prezydent Towarzystwa Hipolita Cegielskiego oraz rektor Uniwersytetu Ekonomicznego w Poznaniu prof. Marian Gorynia-przewodniczący Kapituły Towarzystwa Hipolita Cegielskiego, którzy wręczyli Jubilatowi dyplom Lidera Pracy Organicznej oraz Statuetkę Honorowego Hipolita. Następnie Stefan Barłóg - prezes Zarządu Głównego Towarzystwa Pamięci Powstania Wielkopolskiego złożył gratulacje Jubilatowi oraz zapowiedział wręczenie Nagrody Honorowej Dobosz Powstania Wielkopolskiego, przyznanej prof. Kosmanowi za jego książki o Powstaniu.

Na szczególną uwagę zasługują gratulacje złożone przez przedstawicieli instytucji, z którymi Jubilat był związany i nadal aktywnie współpracuje. Wyrazy wdzięczności i życzenia złożyli m.in.: prof. Tomasz Jasiński - dyrektor Biblioteki Kórnickiej PAN, który przypomniał ogromny wkład prof. Kosmana w rozwój tej instytucji; Stanisław Słopień - prezes Wielkopolskiego Towarzystwa Kulturalnego, wskazał na zaangażowanie Jubilata $w$ realizacji wspólnych projektów oraz jego liczne publikacje na łamach „Przeglądu Wielkopolskiego"; dr Hanka Dmochowska - redaktor naczelna „Przeglądu Zachodniego", dziękowała za wieloletnią współpracę; prof. Anna Pobóg-Lenartowicz - dyrektor Instytutu Historii Uniwersytetu Opolskiego zwróciła uwage na dziesięcioletni opolski okres w karierze naukowej Jubilata.

Odnotować należy także życzenia przesłane przez osoby, które nie mogły uczestniczyć w uroczystości uświetniającej Jubileusz 
prof. Marcelego Kosmana. Były to listy gratulacje nadesłane m.in. przez: prof. Andrzeja Chodubskiego, ks. prof. Zygmunta Zielińskiego oraz prof. Adama Koseskiego - rektora Akademii Humanistycznej w Pultusku. Ryszard Brejza - prezydent Inowrocławia, oprócz gratulacji przekazał także Jubilatowi pejzaż miasta. Z kolei Tadeusz Krokos - prezes kaliskiego Oddziału Polskiego Towarzystwa Historycznego, wspólnie z doktorem Andrzejem Nowakiem - redaktorem naczelnym „Rocznika Kaliskiego”, w piśmie gratulacyjnym, zwrócili uwagę na wielorakie formy współpracy prof. Kosmana z tamtejszym środowiskiem naukowym i kulturalnym.
Jako ostatni głos zabrał sam Jubilat, który podziękował organizatorom uroczystości, licznie zebranym gościom oraz pomysłodawcom księgi pamiątkowej za życzenia i prezenty. Przywołał nazwiska nieżyjących, bardzo bliskich mu Nauczycieli Jana Seredyki i Gerarda Labudy, którzy swoimi artykułami uświetnili księge jubileuszową. Zaznaczył również, że przed nim jeszcze wiele wyzwań w pracy zarówno naukowej, jak i dydaktycznej.

Uroczystą atmosferę dopełniło spotkanie towarzyskie przy tradycyjnym jubileuszowym torcie i toaście $\mathrm{z}$ lampką wina.

Justyna MAGUŚ

Lublin 
